\title{
Effect of standard chemotherapy and antiangiogenic therapy on plasma markers and endothelial cells in colorectal cancer
}

\author{
K S Ramcharan ${ }^{1,2}$, G Y H Lip ${ }^{1}$, P S Stonelake ${ }^{2}$ and A D Blann ${ }^{*}, 1$ \\ ${ }^{1}$ Department of Medicine, University of Birmingham Centre for Cardiovascular Sciences, City Hospital, Dudley Road, \\ Birmingham B18 7QH, UK and '2Department of Surgery, Russell's Hall Hospital, Dudley DY1 2HQ, UK
}

\begin{abstract}
Introduction: The importance of the endothelium in angiogenesis and cancer is undisputed, and its integrity may be assessed by laboratory markers such as circulating endothelial cells (CECs), endothelial progenitor cells (EPCs), plasma von Willebrand factor (vWf), soluble E selectin, vascular endothelial growth factor (VEGF) and angiogenin. Antiantigenic therapy may be added to standard cytotoxic chemotherapy as a new treatment modality. We hypothesised that additional antiangiogenic therapy acts in a contrasting manner to that of standard chemotherapy on the laboratory markers.
\end{abstract}

Methods: We recruited 68 patients with CRC, of whom 16 were treated with surgery alone, 32 were treated with surgery followed by standard chemotherapy (5-flurouracil), and 20 were treated with surgery followed by standard chemotherapy plus anti-VEGF therapy (Avastin). Peripheral blood was taken before surgery, and again 3 months and 6 months later. CD34 ${ }^{+} / C D 45^{-} / C D 146^{+}$ CECs and $\mathrm{CD} 4^{+} / \mathrm{CD} 45^{-} / \mathrm{CD} 309[\mathrm{KDR}]^{+}$EPCs were measured by flow cytometry, plasma markers by ELISA.

Results: In each of the three groups, CECs and EPCs fell at 3 months but were back at pre-surgery levels at 6 months $(P<0.05)$. VEGF was lower in both 3-and 6-month samples in the surgery-only and surgery plus standard chemotherapy groups $(P<0.05)$, but in those on surgery followed by standard chemotherapy plus anti-VEGF therapy, low levels at 3 months $(P<0.01)$ increased to pre-surgery levels at 6 months. In those having surgery and standard chemotherapy, soluble E selectin was lower, whereas angiogenin was higher at 6 months than at baseline (both $P<0.05)$.

Conclusions: We found disturbances in endotheliod cells regardless of treatment, whereas VEGF returned to levels before surgery in those on antiangiogenic therapy. These observations may have clinical and pathophysiological implications.

Cancer is the second most frequent cause of death in North America and Western Europe. In the UK, colorectal cancer is responsible for 14000 of the 142000 cancer deaths annually, with 38000 new cases per year (Cancer Research UK, 2014; UK Government statistics, 2014). Tumour angiogenesis is implicit in the functions of the endothelium, which not only contributes to the structure of the vessel wall but also promotes further neovascularisation (in the local cancer milieu) by producing angiogenic mediators of its own, such as vascular endothelial growth factor (VEGF) and angiogenin (Folkman 1990; Takahashi et al, 1995; Shimoyama et al, 1999). VEGF is a target of therapy for colorectal and many other forms of cancer (Koutras et al, 2011), whereas raised angiogenin in colorectal cancer is associated with disease stage and outcome after surgery (Shimoyama et al, 1999). Furthermore, there are several other lines of evidence of endothelial activity or perturbation in cancer, such as increased release of endothelial cell-specific molecules von Willebrand factor (vWf) and soluble E selectin into the plasma, as are present in colorectal cancer (Gil-Bazo et al, 2005; Sata et al, 2010).

More recently, increased numbers of endotheloid cells (cells with endothelial-like morphology and phenotype), have been described in peripheral blood of patients with various solid 
tumours including colorectal cancer, the origins of which are the subject of much debate (Beerepoot et al, 2004; Fürstenberger et al, 2006; Rowand et al, 2007; Dome et al, 2008). These cells may arise from existing normal and/or tumour vasculature (known as mature circulating endothelial cells (CECs)) or may represent endothelial progenitor cells (EPCs) derived from stem cells (probably from the bone marrow) that may contribute to neovascularisation (Blann and Pretorius, 2006). Differences in EPCs and CECs numbers may therefore represent the balance of injury and repair to blood vessels, and/or the neovascularisation required of tumour angiogenesis. If endotheliod cells are indeed crucial to neovascularisation, this would make them a legitimate target (Ding et al, 2008; Mancuso and Bertolini, 2010). However, we have argued that one or even two markers of vascular perturbation used in isolation are insufficient to fully describe changes to the endothelium and in angiogenesis in cancer, and that a combination of types of methods (e.g. cell markers should be used alongside plasma markers) will provide a more complete view of tumour biology (Blann et al, 2011).

Standard treatment of cytotoxic chemotherapy alone has been challenged by the concurrent use of antiangiogenic therapy (Hurwitz et al, 2004; Gil-Bazo et al, 2005; Fürstenberger et al, 2006; Koutras et al, 2011). We hypothesised that adding antiangiogenic therapy produces different responses in cellular (EPCs, CECs) and plasma (vWf, soluble E selectin) markers of vascular perturbation, and plasma growth factors (VEGF, angiogenin). We tested our hypothesis in three groups of patients with colorectal cancer undergoing treatment (surgery alone, surgery plus chemotherapy alone, surgery plus chemotherapy and antiangiogenic therapy), taking blood before surgery and again 3 and 6 months later.

\section{MATERIALS AND METHODS}

Patients were recruited from among those scheduled to undergo surgery for colorectal cancer at a large urban University Hospital. Standard surgical primary tumour resections were carried out with associated mesocolic/mesorectal lymphadenectomy. Specimens were sent for routine histology and the Dukes' stage derived according to standard criteria (Dukes, 1932; Astler and Coller, 1954). Exclusion criteria were concurrent inflammatory connective tissue disease (e.g. rheumatoid arthritis), other neoplasia, marked haematological (full blood count) or biochemical (U\&Es) abnormalities, for example, anaemia and renal disease $(e G F R<30)$ and certain medications (antibiotics, NSAIDs, HRT and anticoagulant therapy). Local research ethics committee approval and informed written consent from all subjects were obtained.

Three months after surgery, a second blood sample was obtained. A clinical decision was then taken to proceed with no further treatment, with local standard chemotherapy based on 5 -flurouracil with or without antiangiogenic therapy. Chemotherapy was based on a modified de Gromant regime (leucovorin [folinic acid] + 5-fluorouracil [5-FU]) regime. For stage 2 (Dukes' B) disease this was 5-FU $400 \mathrm{mg} \mathrm{m}^{-2}$ IV bolus, followed by 5 -FU $1200 \mathrm{mg} \mathrm{m}^{-2}$ per day IV $\times 2$ days (total $2400 \mathrm{mg} \mathrm{m}^{-2}$ ) as a $46-48 \mathrm{~h}$ continuous infusion, repeated every 2 weeks. Oxaliplatin [Eloxatin] + leucovorin [folinic acid] + 5-fluorouracil [5-FU]) was mainly for stage 3 (Dukes' C) disease as follows. Day 1: Oxaliplatin $85 \mathrm{mg} \mathrm{m}^{-2}$ IV over $2 \mathrm{~h}+$ leucovorin $400 \mathrm{mg} \mathrm{m}^{-2}$ IV over $2 \mathrm{~h}$, followed by 5 -FU $400 \mathrm{mg} \mathrm{m}^{-2}$ IV bolus, followed by 5 -FU $1200 \mathrm{mg} \mathrm{m}^{-2}$ per day IV $\times 2$ days (total $2400 \mathrm{mg} \mathrm{m}^{-2}$ ) as a $46-48 \mathrm{~h}$ continuous infusion, repeated every 2 weeks (Cheeseman et al, 2002, 2008; André et al, 2004, 2009; Twelves et al, 2005). In some cases, treatment was days 1-14 Capecitabine [Xeloda] $1250 \mathrm{mg} \mathrm{m}^{-2}$ orally twice daily for 2 weeks. The cycle was repeated every 3 weeks for 8 cycles over a 6 months altogether.
For those on antiangiogenic therapy, bevacizumab (Hurwitz et al, 2004) $\left(5 \mathrm{mg} \mathrm{kg}^{-1}\right)$ was given IV on the first day of each 3 week cycle, and then $5 \mathrm{mg} \mathrm{kg}^{-1}$ every 2 weeks. A third blood sample was obtained from subjects in all three group after a further 3 months.

Blood was taken for CECs and EPCs, and for plasma markers. For the latter, blood was centrifuged at $2500 \mathrm{rpm}(=1000 \mathrm{~g})$ for $20 \mathrm{~min}$ to provide plasma for VEGF, angiogenin, soluble E selectin (CD69E) and vWf. Plasma was stored frozen at $-70{ }^{\circ} \mathrm{C}$ for batch analysis by ELISA (R\&D Systems, Abingdon, UK; Dako-Patts, Ely, Cambs, UK). Intra-assay and inter-assay coefficients of variation (CVs) were $<5 \%$ and $<10 \%$, respectively.

EPCs and CECs were analysed by flow cytometry (FACScalibur, Becton Dickinson, Oxford, UK)(Goon et al, 2009; Blann et al, 2011). In brief, to $200 \mu \mathrm{l}$ of blood was added $10 \mu \mathrm{l}$ each of fluorochrome-labelled antibodies to CD45, CD146, CD34 and CD309 (all Becton Dickinson except anti-CD309, R\&D Systems). Blood was incubated in the dark at room temperature for $20 \mathrm{~min}$, then 3-ml red cell lysing/fixative solution (Becton Dickinson) was added and the tube and incubated for $15 \mathrm{~min}$ on the bench. Excess reagents were washed out with cycles of centrifugation $(200 \mathrm{~g}$ for $5 \mathrm{~min}$ ) and $3 \mathrm{ml}$ of PBS solution. After the final wash, $0.5 \mathrm{ml}$ of PBS was added and the suspension was applied to the FACScalibur. The CellQuest Pro software of Apple G4 computer was used to determine cell counts with a minimum of 100000 events. White blood cells were identified and excluded by SSC and FSC in conjunction with CD45-PerCP as it is established that some white blood cells may also express endothelial and/or stem cell markers (Beerepoot et al, 2004; Fürstenberger et al, 2006; Rowand et al, 2007; Ding et al, 2008; Dome et al, 2008; Mancuso and Bertolini, 2010). CD34-APC + ve cells were then gated and subsequently re-probed in separate analyses with CD309-PE and CD45-PerCP for EPCs or with CD146-FITC and CD45-PerCP for CECs. Intraand inter-assay CVs were $<24 \%$ for EPCs $<47 \%$ for CECs, $<40 \%$ for EPCs and $<60 \%$ for CECs, respectively.

Statistics. Data are presented as mean and s.d. (when data normally distributed) or median and interquartile range (non-normally distributed). Comparison of the three groups at baseline was by analysis of variance (ANOVA) or the KruskalWallis test. The $\chi^{2}$ test was used for categorical data. Differences over the two time points were sought using paired $t$-test or Wilcoxon's test, at three time points by a general linear model ANOVA. We included the routine white blood cell count, known to be raised in colorectal cancer (Kemeny and Braun, 1983), in our analyses to provide a perspective for CEC and EPC results. A sample size of 66 yields $2 P<0.02$ and $1-$ beta $=0.85$ to robustly defend a (Spearman) correlation coefficient of $r>0.4$. All analyses were performed on Minitab release 16 and $P<0.05$ was taken to assume significance.

\section{RESULTS}

Clinical and demographic details of the patients are shown in Table 1. There were no differences in sex, age, blood pressure, heart rate, family history of cancer, smoking and body mass index between the groups. There was, however, a difference in distribution of Dukes' stage between the groups. Subjects with a higher Dukes' stage were more likely to have chemotherapy with or without antiangiogenic therapy. Table 2 shows research data before surgery from each of the three treatment groups. With the exception of soluble E selectin being higher in those on standard chemotherapy. There were no differences in these indices at baseline between the groups. Table 3 shows changes in research indices in the entire cohort of 68 patients before and 3 months after their surgery but before additional adjunct therapy. All indices except total CD34 + ve cells were lower after surgery. 
Table 1. Clinical and demographic details of the subjects

\begin{tabular}{|c|c|c|c|c|}
\hline & $\begin{array}{c}\text { Group } 1 \text { surgery } \\
\text { only }(n=16)\end{array}$ & $\begin{array}{c}\text { Group } 2 \text { standard } \\
\text { chemotherapy }(n=32)\end{array}$ & $\begin{array}{l}\text { Group } 3 \text { anti-VEGF } \\
\text { therapy }(n=20)\end{array}$ & $P$-value \\
\hline Age (years) & $71.2(9.3)$ & $70.9(7.9)$ & $70.7(7.9)$ & 0.988 \\
\hline Sex male/female (n) & $9 / 7$ & $18 / 14$ & $10 / 10$ & 0.895 \\
\hline BMI $\left(\mathrm{kg} \mathrm{m}^{-2}\right)$ & $28.4(3.1)$ & $27.7(2.6)$ & $26.2(2.4)$ & 0.041 \\
\hline Systolic blood pressure $(\mathrm{mm} \mathrm{Hg})$ & $121(13)$ & $123(9)$ & $122(10)$ & 0.876 \\
\hline Diastolic blood pressure $(\mathrm{mm} \mathrm{Hg})$ & $74(8)$ & $75(10)$ & $74(7)$ & 0.732 \\
\hline Dukes' stage $(A / B / C / D)(n)$ & 9/5/1/1 & $2 / 13 / 8 / 9$ & $0 / 5 / 11 / 4$ & $<0.001$ \\
\hline Major tumour site (colon/rectum)(n) & $12 / 4$ & $22 / 10$ & $10 / 10$ & 0.239 \\
\hline Tumour size $(\mathrm{mm})$ & $37(17)$ & $47(24)$ & $43(17)$ & 0.282 \\
\hline Number of nodes excised (n) & $10.5(8.5-12)$ & $12(8.25-18.7)$ & $11.5(10.25-18.75)$ & 0.321 \\
\hline
\end{tabular}

Data are mean (s.d.), median (interquartile range), absolute number (n) or percentage. Analysed by ANOVA, Kruskal-Wallis or $\chi^{2}$ as appropriate.

\section{Table 2. Research indices at baseline}

\begin{tabular}{|c|c|c|c|c|}
\hline & $\begin{array}{c}\text { Group } 1 \text { surgery } \\
\text { only }(n=16)\end{array}$ & $\begin{array}{l}\text { Group } 2 \text { surgery } \\
\text { plus standard } \\
\text { chemotherapy }(n=32)\end{array}$ & $\begin{array}{l}\text { Group } 3 \text { surgery plus standard } \\
\text { chemotherapy and anti-VEGF } \\
\text { therapy }(n=20)\end{array}$ & $P$-value \\
\hline Circulating endothelial cells (cells ml ${ }^{-1}$ ) & $4(0-19)$ & $12(0-19)$ & $11(7-48)$ & 0.746 \\
\hline Endothelial progenitor cells (cells ml ${ }^{-1}$ ) & $13(0-39)$ & $16(9-44)$ & $21(10-39)$ & 0.749 \\
\hline Von Willebrand factor (IU dl $\left.{ }^{-1}\right)$ & $115(22)$ & $123(33)$ & $121(30)$ & 0.659 \\
\hline Soluble E selectin ( $\mathrm{ng} \mathrm{ml}^{-1}$ ) & $31(9)$ & $34(12)^{*}$ & $26(8)^{*}$ & 0.029 \\
\hline VEGF $\left(p g \mathrm{ml}^{-1}\right)$ & $120(10-494)$ & $320(30-1200)$ & $500(40-1000)$ & 0.160 \\
\hline Angiogenin $\left(\mathrm{ng} \mathrm{ml}^{-1}\right.$ ) & $308(75)$ & $282(97)$ & $319(97)$ & 0.231 \\
\hline CD34 + ve cells (cells ml ${ }^{-1}$ ) & $849(638-1167)$ & $781(417-1315)$ & $781(585-1123)$ & 0.839 \\
\hline White cell count $\left(\times 10^{6} \mathrm{ml}^{-1}\right)$ & $6.7(1.6)$ & $7.9(2.2)$ & $6.7(1.5)$ & $0.046^{\mathrm{a}}$ \\
\hline \multicolumn{5}{|c|}{$\begin{array}{l}\left.\text { Data are mean (s.d.) or median (interquartile range). Analysed by ANOVA, }{ }^{*} P<0.05 \text { (Tukey's post hoc test). Reference ranges from a control population (reference } 34\right) \text { are circulating endothelia } \\
\text { cells } 0(0-8) \text {, endothelial progenitor cells } 7(0-12) \text {, von Willebrand factor } 110(31) \text {, soluble E selectin } 22(10) \text {, VEGF } 32(0-82) \text {, angiogenin } 143(107-175) \text { and white cell count } 5.8(1.3) \text {. We do no } \\
\text { have a reference range for CD } 34+\text { ve cells. } \\
{ }^{a} \text { No significant inter-group differences. }\end{array}$} \\
\hline
\end{tabular}

Table 3. Research indices before and 3 months after surgery in 68 patients

\begin{tabular}{|c|c|c|c|}
\hline & $\begin{array}{l}\text { Before } \\
\text { surgery }\end{array}$ & $\begin{array}{l}\text { Three } \\
\text { months } \\
\text { after } \\
\text { surgery }\end{array}$ & $P$-value \\
\hline $\begin{array}{l}\text { Circulating endothelial cells } \\
\text { (cells } \mathrm{ml}^{-1} \text { ) }\end{array}$ & $10(0-20)$ & $0(0-10)$ & 0.001 \\
\hline $\begin{array}{l}\text { Endothelial progenitor cells } \\
\left(\text { cells ml }{ }^{-1} \text { ) }\right.\end{array}$ & $17(2.3-40)$ & $0(0-9)$ & $<0.001$ \\
\hline Von Willebrand factor $\left(\mathrm{IU} \mathrm{dl}^{-1}\right)$ & $121(30)$ & $110(25)$ & 0.018 \\
\hline Soluble E selectin $\left(\mathrm{ng} \mathrm{ml}^{-1}\right)$ & $31(11)$ & $26(12)$ & 0.024 \\
\hline VEGF $\left(p g \mathrm{ml}^{-1}\right)$ & $310(30-771)$ & $23(12.5-51)$ & $<0.001$ \\
\hline Angiogenin $\left(\mathrm{ng} \mathrm{ml}^{-1}\right)$ & 301 (94) & $238(100)$ & $<0.001$ \\
\hline CD34 + ve cells (cells ml ${ }^{-1}$ ) & $\begin{array}{c}74(51.5- \\
109.5)\end{array}$ & $96.5(58-131)$ & 0.065 \\
\hline White cell count $\left(\times 10^{6} \mathrm{ml}^{-1}\right)$ & $7.3(2.0)$ & $5.4(1.5)$ & $<0.001$ \\
\hline
\end{tabular}

Table 4 shows data from 16 patients treated with surgery alone. Although overall, CEC numbers changed significantly, this was so minor that there was no specific inter-group difference. EPCs and VEGF fell from baseline to 3 months (both $P<0.05$ ). At 6 months, VEGF remained low $(P<0.05)$, but the EPC count was not different from baseline. There were no significant changes in $\mathrm{vWf}$, soluble E selectin, angiogenin, CD34 + ve cells or the white cell count. Changes in EPC and CEC counts are shown in Figures 1A and $2 \mathrm{~A}$, respectively.

Table 5 shows data from 32 patients treated with standard chemotherapy. CECs were lower at 3 months $(P<0.05)$, but at 6 months, were no different to baseline levels. EPCs numbers fell at 3 months $(P<0.01)$ but had returned to baseline levels at 6 months $(P<0.05$ to numbers at 3 months). Soluble E selectin was lower at 6 months compared with baseline and 3 months (both $P<0.05$ ). VEGF and the white cell count were lower at 3 and 6 months compared with baseline (both $P<0.01$ ). Levels of angiogenin fell from baseline to 3 months $(P<0.05)$, but then increased from 3 months to 6 months $(P<0.01)$. Changes in EPC and CEC counts are shown in Figures $1 \mathrm{~B}$ and $2 \mathrm{~B}$, respectively.

Table 6 shows data from patients on standard chemotherapy and antiangiogenic therapy. The numbers of CECs fell to 3 months $(P<0.01)$, then increased to 6 months $(P<0.05)$. The numbers of EPC and VEGF levels fell to 3 months and then increased to 6 months (all $P<0.01$ ). There were no changes in vWf or 


\begin{tabular}{|c|c|c|c|c|}
\hline & Baseline & 3 months & 6 months & $P$-value \\
\hline Circulating endothelial cells (cells ml ${ }^{-1}$ ) & $4(0-19)$ & $0(0-9)$ & $8(0-10)$ & 0.045 \\
\hline Endothelial progenitor cells (cells ml ${ }^{-1}$ ) & $13(0-39)$ & $0(0-9)$ & $8(0-10)$ & $0.036^{a}$ \\
\hline Von Willebrand factor (IU dl $\left.{ }^{-1}\right)$ & $115(22)$ & $106(19)$ & $118(30)$ & 0.441 \\
\hline Soluble E selectin $\left(\mathrm{ng} \mathrm{ml}^{-1}\right)$ & $31(9)$ & $26(9)$ & $29(11)$ & 0.302 \\
\hline VEGF $\left(\mathrm{pg} \mathrm{ml}^{-1}\right)$ & $120(10-494)$ & $23(6-23)$ & $16(5-82)$ & $0.024^{b}$ \\
\hline Angiogenin $\left(\mathrm{ng} \mathrm{ml}^{-1}\right)$ & $308(75)$ & $235(97)$ & $300(96)$ & 0.061 \\
\hline CD34+ ve cells (cells ml ${ }^{-1}$ ) & $849(638-1167)$ & $1083(679-1603)$ & $918(500-1269)$ & 0.395 \\
\hline White cell count $\left(\times 10^{6} \mathrm{ml}^{-1}\right)$ & $6.7(1.6)$ & $5.7(1.7)$ & $6.2(1.3)$ & 0.175 \\
\hline \multicolumn{5}{|c|}{$\begin{array}{l}\text { Data are mean (s.d.) or median (interquartile range). P-value by ANOVA. } \\
a_{P}<0.05 \text {, baseline to 3-month point. } \\
b_{P<0.05} \text {, baseline to 3-month and 6-month points. }\end{array}$} \\
\hline
\end{tabular}

Table 5. Research indices in 32 patients in Group 2 (surgery followed by standard chemotherapy)

\begin{tabular}{|c|c|c|c|c|}
\hline & Baseline & 3 months & 6 months & $P$-value \\
\hline Endothelial progenitor cells (cells ml ${ }^{-1}$ ) & $16(9-44)$ & $0(0-11)$ & $10(8-15)$ & $<0.001^{b}$ \\
\hline Von Willebrand factor $\left(\mathrm{IU} \mathrm{dl}^{-1}\right)$ & $123(33)$ & $106(25)$ & $119(28)$ & 0.08 \\
\hline Soluble E selectin $\left(\mathrm{ng} \mathrm{ml}^{-1}\right)$ & $34(12)$ & $38(9)$ & $24(10)$ & $0.007^{c}$ \\
\hline VEGF $\left(p g \mathrm{ml}^{-1}\right)$ & $320(30-1200)$ & $30(20-287)$ & $30(21-310)$ & $0.001^{d}$ \\
\hline CD34 + ve cells (cells ml ${ }^{-1}$ ) & 781 (417-1315) & 839 (583-1212) & $686(361-1056)$ & 0.304 \\
\hline White cell count $\left(\times 10^{6} \mathrm{ml}^{-1}\right)$ & $7.9(2.2)$ & $5.4(1.3)$ & $5.8(2.0)$ & $<0.001^{\mathrm{d}}$ \\
\hline \multicolumn{5}{|c|}{ 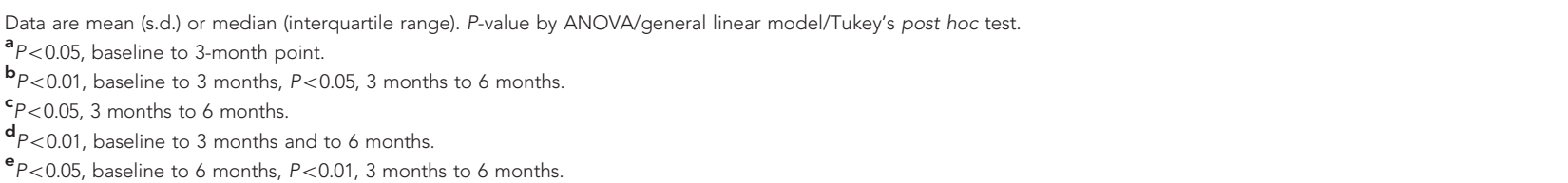 } \\
\hline
\end{tabular}

angiogenin. CD34 + cell numbers were lower at 6 months than at baseline, whereas the white blood cell count fell at 3 months $(P<0.01)$ and at 6 months $(P<0.02)$ compared with baseline. Changes in EPC and CEC counts are shown in Figures $1 \mathrm{C}$ and $2 \mathrm{C}$, respectively.

At baseline, there were significant Spearman correlations between EPCs and CECs $(r=0.7, P<0.001)$, between VEGF and CECs $(r=0.55, P<0.001)$ and between VEGF and EPCs $(r=0.69$, $P<0.001)$. At 3 months, these relationships were still present but were less strong at $r=0.52(P<0.001), r=0.28(P=0.019)$ and $r=0.25(P=0.037)$, respectively, although the latter two may be false negatives as we are only powered for $r>0.4$. At 6 months, only that between CECs and EPCs was significant at $r=0.45$, $P<0.001$; the VEGF relationships being $r=-0.16, P=0.193$ with CECs and $r=0.25, P=0.037$ with EPCs.

\section{DISCUSSION}

Angiogenesis, possibly driven by growth factors such as VEGF and angiogenin (Folkman, 1990; Takahashi et al, 1995; Shimoyama et al, 1999) is a leading factor in the pathophysiology of cancer. Increased number of endotheloid cells in the blood may also have a role in this disease (Beerepoot et al, 2004; Fürstenberger et al, 2006; Rowand et al, 2007; Dome et al, 2008). EPCs may be surrogates of the effects of anti-VEGF therapy (Takahashi et al, 1995; Gupta, 2007; Ronzoni et al, 2010; Matsusaka et al, 2011), as VEGF may partially drive EPCs mobilisation from the bone marrow (Asahara et al, 1999; Li et al, 2006). Indeed, the strong relationships of VEGF with CECs and EPCs at baseline to some extent support this hypothesis, although the weakening of these relationships as treatment proceeds casts some doubt. As research in this area is hindered by the lack of consensus as to which CD markers best define these cells (Takahashi et al, 1995; Asahara et al, 1999; Beerepoot et al, 2004; Blann and Pretorius, 2006; Fürstenberger et al, 2006; Li et al, 2006; Gupta 2007; Rowand et al, 2007; Ding et al, 2008; Dome et al, 2008; Goon et al, 2009; Mancuso and Bertolini, 2010; Bellows et al, 2011; Blann et al, 2011; Ramcharan et al, 2013), cross-comparisons can be difficult. Nevertheless, endotheloid cells measured before treatment seem to be good markers of outcome (Ronzoni et al, 2010; Matsusaka et al, 2011) and reflect Dukes' stage (Ramcharan et al, 2013). However, few studies have examined a comprehensive panel of vascular and growth factor markers before and after standard chemotherapy and antiangiogenic therapy.

In the entire group, reductions in all research indices (except CD34 + cells) 3 months after surgery were all as expected, and, despite reduced power, this reduction was found in all three subgroups before additional therapy. These findings fit with the general hypothesis of a link between these markers and the tumour load. However, a consistent finding was that the numbers of both 
A

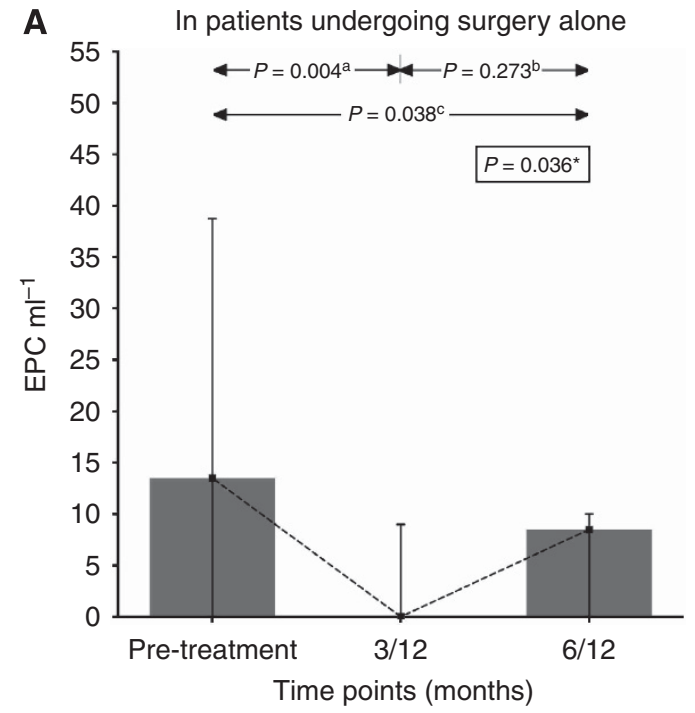

B In patients undergoing

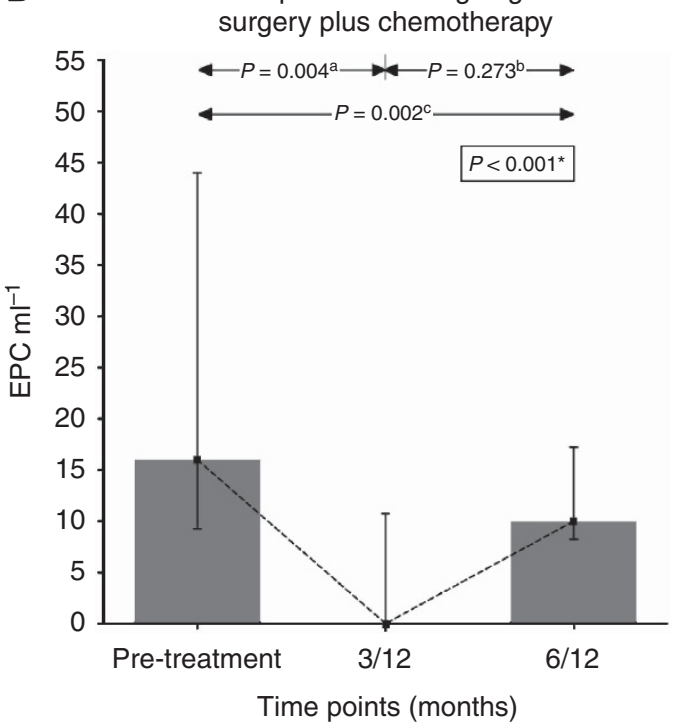

C In patients undergoing

surgery chemotherapy and anti-VEGF therapy

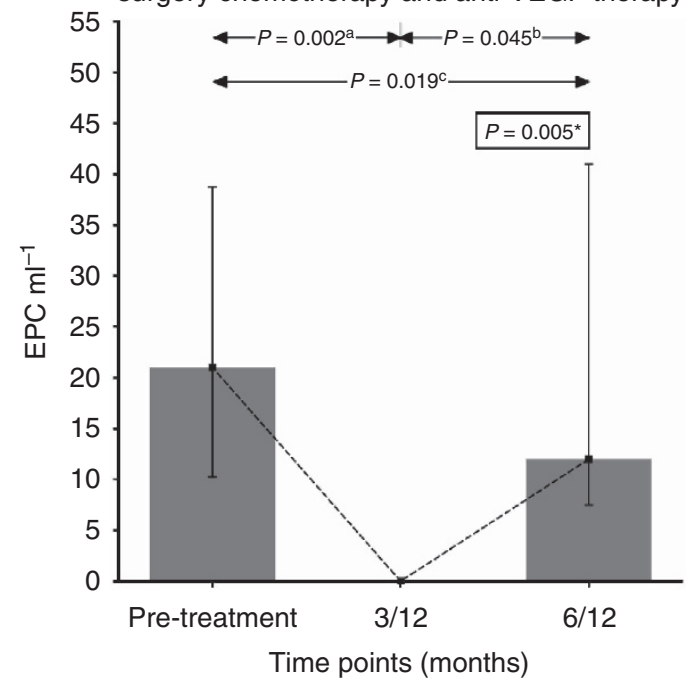

Figure 1. Changes in EPC numbers. (A) In patients undergoing surgery alone. (B) In patients underoing surgery plus chemotherapy. (C) In patients underoing surgery plus chemotherapy and anti-VEGF therapy. *Overall $P$-value. ${ }^{a}$ Between baseline and 3 months; ${ }^{b}$ Between 3 and 6 months; ${ }^{\mathrm{c} B e t w e e n}$ baseline and 6 months. Data median (interquartile range).
A In patients undergoing surgery alone

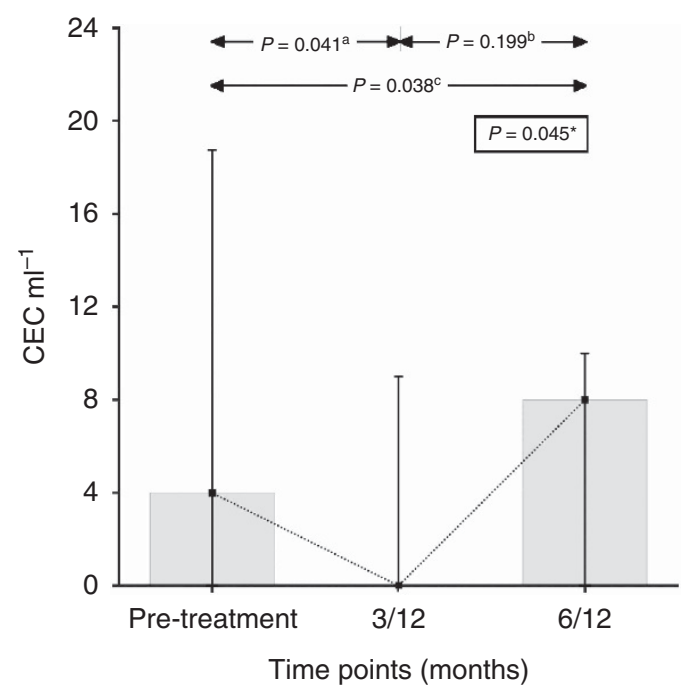

B In patients undergoing surgery plus

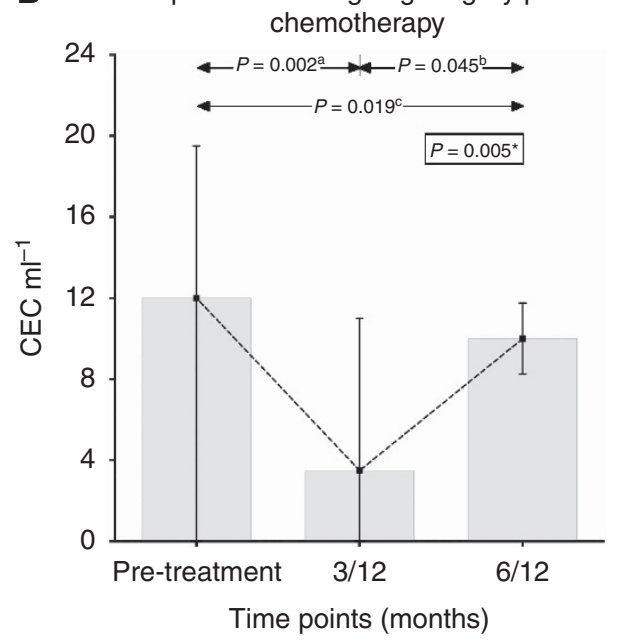

C In patients undergoing surgery plus chemotherapy and anti-VEGF therapy

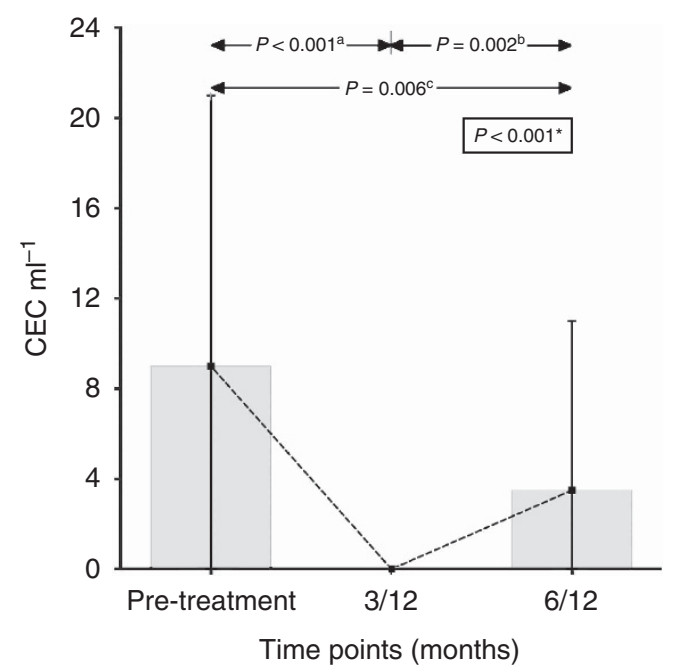

Figure 2. Changes in CEC numbers. (A) In patients undergoing surgery alone. (B) In patients underoing surgery plus chemotherapy. (C) In patients underoing surgery plus chemotherapy and anti-VEGF therapy.

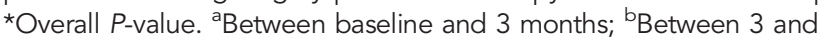
6 months; ${ }^{c}$ Between baseline and 6 months. Data median (interquartile range). 


\begin{tabular}{|c|c|c|c|c|}
\hline & Baseline & 3 months & 6 months & $P$-value \\
\hline Circulating endothelial cells (cells ml ${ }^{-1}$ ) & $21(7-60)$ & $0(0-13)$ & $11(7-48)$ & $0.005^{a}$ \\
\hline Endothelial progenitor cells (cells ml ${ }^{-1}$ ) & $21(10-39)$ & $0(0-0)$ & $12(7-32)$ & $<0.001^{\mathrm{b}}$ \\
\hline Von Willebrand factor $\left(I U \mathrm{dl}^{-1}\right)$ & $121(30)$ & $122(26)$ & $122(15)$ & 0.943 \\
\hline Soluble E selectin $\left(\mathrm{ng} \mathrm{ml}^{-1}\right)$ & $26(8)$ & $22(15)$ & $29(12)$ & 0.195 \\
\hline VEGF $\left(\mathrm{pg} \mathrm{ml} l^{-1}\right)$ & $500(40-1000)$ & $30(23-55)$ & $770(630-1900)$ & $<0.001^{b}$ \\
\hline Angiogenin $\left(\mathrm{ng} \mathrm{ml}^{-1}\right)$ & $319(97)$ & $255(117)$ & $317(87)$ & 0.074 \\
\hline CD34+ve cells (cells ml ${ }^{-1}$ ) & $781(585-1123)$ & 595 (427-1139) & $291(192-535)$ & $0.003^{c}$ \\
\hline White cell count $\left(\times 10^{6} \mathrm{ml}^{-1}\right)$ & $6.7(1.5)$ & $5.1(1.7)$ & $5.3(1.4)$ & $0.003^{d}$ \\
\hline \multicolumn{5}{|c|}{$\begin{array}{l}\text { Data are mean (s.d.) or median (interquartile range). } \\
a_{P}<0.01 \text {, baseline to } 3 \text { months, } P<0.05,3 \text { months to } 6 \text { months. } \\
b_{P} \text {, } \\
c_{P}<0.01 \text {, baseline to } 3 \text { months and baseline to } 6 \text { months. } \\
d_{P<0.01 \text {, baseline to } 6 \text { months. }} \text { months. } P<0.02 \text { baseline to } 6 \text { months. }\end{array}$} \\
\hline
\end{tabular}

endotheloid cells increased regardless of the presence or absence of adjunct chemotherapy and antiangiogenic therapy. We are unable to offer a simple explanation for the increase in both cell populations after an additional 3 months. It may be that the rise in both EPCs and CECs in those not going on chemotherapy reflects the response of the body to some residual unexcised tumour and/or the physiology of repair. The rise in EPCs and CECs in those on both regimes of pharmacotherapy may be a drug-related response to these agents, or it may reflect the failure of these drugs to suppress the increase in cell numbers after surgery. However, Willett et al (2005) reported that CECs numbers fell in five rectal cancer patients after 3 days of $5 \mathrm{mg} \mathrm{kg}^{-1}$ anti-VEGF therapy, but after 12 days they had returned to pre-treatment levels. In contrast, in our study, white cell counts generally fell after surgery, and remained low at 6 months, whereas CD34 + ve cells remained constant in two groups, but fell after 6 months in those on antiangiogenic therapy. The reason for the latter is unclear.

Increased circulating VEGF is an established feature of colorectal cancer (Fujisaki et al, 1998; Werther et al, 2000; De Vita et al, 2004) and predict Dukes' stage (Kumar et al, 1998; Bellows et al, 2011). It was therefore no surprise to find that levels fell after tumour excision, and remained low at 6 month in the no chemotherapy and standard chemotherapy groups. As expected from animal and clinical studies, levels of plasma VEGF increased in those on antiangiogenic activity (Willett et al, 2005; Segerstrom et al, 2006), and may represent both free and antibody-bound VEGF (Yang et al, 2003). Levels of angiogenin are also raised in colorectal cancer (Shimoyama et al, 1999; Ramcharan et al, 2013), as they are in other cancers (Fang et al, 2011; Landt et al, 2011; Rykala et al, 2011), and although levels fell modestly 3 months after surgery in all three groups (as did VEGF), they returned to baseline at 6 months (unlike VEGF in those in the first two groups). However, in those on standard chemotherapy, levels of angiogenin were higher than at baseline. As it is presumed that excess plasma angiogenin levels arise (as does excess VEGF (Ramcharan et al, 2013)) from neoplastic cells, this perhaps implies the presence of some residual tumour 6 months after surgery. Alternatively, raised levels in those on standard chemotherapy may be due to a nonspecific effect of the drugs on unspecified somatic cells.

In the entire cohort, levels of vascular markers soluble E selectin and vWf (Gil-Bazo et al, 2005; Sato et al, 2010) both fell after surgery, probably reflecting less vascular perturbation resulting from a reduction in tumour load. However, in each of the three subgroups, differences were not marked, and there was no clear pattern, suggesting overtly damaging effect of standard chemotherapy with or without antiangiogenic therapy on the endothelium. The population variances (standard deviation/interquartile range) of these molecules are relatively large, and are not specific for cancer, and so we cannot exclude the possibility of a false negative owing to the small number of patients in each of the intervention groups. Despite this, soluble E selectin may be involved in angiogenesis (Koch et al, 1995; Kumar et al, 2003; Belotti et al, 2012) and vasculogenesis (Oh et al, 2007), although (in breast cancer) this has been disputed (Hebber and Peyrat, 2000). In our hands, although soluble E selectin fell significantly in the entire cohort, this was due to a marked fall in those on surgery plus standard chemotherapy alone (the largest group of 32 patients): there was no significant change in those on surgery alone $(n=16)$ or those on surgery plus standard chemotherapy plus anti-VEGF therapy $(n=20)$. Once more, small number of patients per group leads us to be cautious in speculating that we are witnessing a genuine reduction in angiogenesis per se, in only one of the three treatment groups, or simply a nonspecific response of the endothelium to the different types of treatment.

We accept the limitation of the small number of patients in each group, and despite this, some of the changes were highly significant. We therefore stand by what we feel is our major result, which is that numbers of CECs and EPCs fall markedly 3 months after surgery, but increase after a further 3 months regardless of treatment. This calls into doubt the value of a single measurement of these cells as markers of disease activity or outcome in either the short or long term.

\section{REFERENCES}

André T, Boni C, Mounedji-Boudiaf L, Navarro M, Tabernero J, Hickish T, Topham C, Zaninelli M, Clingan P, Bridgewater J, Tabah-Fisch I, de Gramont A (2004) Oxaliplatin, fluorouracil, and leucovorin as adjuvant treatment for colon cancer. N Engl J Med 350: 2343-2351.

André T, Boni C, Navarro M, Tabernero J, Hickish T, Topham C, Bonetti A, Clingan P, Bridgewater J, Rivera F, de Gramont A (2009) Improved overall survival with oxaliplatin, fluorouracil, and leucovorin as adjuvant treatment in stage II or III colon cancer in the MOSAIC trial. J Clin Oncol 27: 3109-3116.

Asahara T, Takahashi T, Masuda H, Kalka C, Chen D, Iwaguro H, Inai Y, Silver M, Isner JM (1999) VEGF contributes to postnatal neovascularization by mobilizing bone marrow-derived endothelial progenitor cells. EMBO J 18: 3964-3972.

Astler VB, Coller FA (1954) The prognostic significance of direct extension of carcinoma of the colon and rectum. Ann Surg 139: 846. 
Beerepoot LV, Mehra N, Vermaat JS, Zonnenberg BA, Gebbink MF, Voest EE (2004) Increased levels of viable circulating endothelial cells are an indicator of progressive disease in cancer patients. Ann Oncol 15: 139-145.

Belotti A, Elli E, Speranza T, Lanzi E, Pioltelli P, Pogliani E (2012) Circulating endothelial cells and endothelial activation in essential thrombocythemia: results from $\mathrm{CD} 146+$ immunomagnetic enrichment-flow cytometry and soluble E-selectin detection. Am J Hematol 87: 319-320.

Bellows CF, Zhang Y, Chen J, Frazier ML, Kolonin MG (2011) Circulation of progenitor cells in obese and lean colorectal cancer patients. Cancer Epidemiol Biomarkers Prev 20: 2461-2468.

Blann AD, Pretorius A (2006) Circulating endothelial cells and endothelial progenitor cells: two sides of the same coin, or two different coins? Atherosclerosis 188: 12-18.

Blann AD, Balakrishnan B, Shantsila E, Ryan P, Lip GY (2011) Endothelial progenitor cells and circulating endothelial cells in early prostate cancer: a comparison with plasma vascular markers. Prostate 71: 1047-1053.

Cancer Research UK (2014) http://info.cancerresearchuk.org/utilities/ atozindex/atoz-bowel-cancer.

Cassidy J, Clarke S, Díaz-Rubio E, Scheithauer W, Figer A, Wong R, Koski S, Lichinitser M, Yang TS, Rivera F, Couture F, Sirzén F, Saltz L (2008) Randomized phase III study of capecitabine plus oxaliplatin compared with fluorouracil/folinic acid plus oxaliplatin as first-line therapy for metastatic colorectal cancer. J Clin Oncol 26: 2006-2012.

Cheeseman SL, Joel SP, Chester JD, Wilson G, Dent JT, Richards FJ, Seymour MT (2002) A 'modified de Gramont' regimen of fluorouracil, alone and with oxaliplatin, for advanced colorectal cancer. Br J Cancer 87: 393-399.

De Vita F, Orditura M, Lieto E, Infusino S, Morgillo F, Martinelli E, Castellano P, Romano C, Ciardiello F, Catalano G, Pignatelli C, Galizia G (2004) Elevated perioperative serum vascular endothelial growth factor levels in patients with colon carcinoma. Cancer 100: 270-278.

Ding YT, Kumar S, Yu DC (2008) The role of endothelial progenitor cells in tumour vasculogenesis. Pathobiology 75: 265-273.

Dome D, Dobos J, Tovari J, Paku S, Kovacs G, Ostoros G, Timar J (2008) Circulating bone marrow-derived endothelial progenitor cells: characterization, mobilization, and therapeutic considerations in malignant disease. Cytometry A 73: 186-193.

Dukes CE (1932) The classification of cancer of the rectum. J Pathol Bacteriol 35: 323.

Fang S, Repo H, Joensuu H, Orpana A, Salven P (2011) High serum angiogenin at diagnosis predicts for failure on long-term treatment response and for poor overall survival in non-Hodgkin lymphoma. Eur $J$ Cancer 47: 1708-1716.

Folkman J (1990) What is the evidence that tumors are angiogenesis dependent? J Natl Cancer Inst 82: 4-6.

Fujisaki K, Mitsuyama K, Toyonaga A, Matsuo K, Tanikawa K (1998) Circulating vascular endothelial growth factor in patients with colorectal cancer. Am J Gastroenterol 93: 249-252.

Fürstenberger G, von Moos R, Lucas R, Thürlimann B, Senn HJ, Hamacher J, Boneberg EM (2006) Circulating endothelial cells and angiogenic serum factors during neoadjuvant chemotherapy of primary breast cancer. $\mathrm{Br} \mathrm{J}$ Cancer 94: 524-531.

Gil-Bazo I, Catalán Goni V, Alonso Gutiérrez A, Rodríguez Rodríguez J, Páramo Fernández JA, de la Cámara Gómez J, Hernández Lizoain JL, García-Foncillas López J (2005) Impact of surgery and chemotherapy on von Willebrand factor and vascular endothelial growth factor levels in colorectal cancer. Clin Transl Oncol 7: 150-155.

Goon PK, Lip GY, Stonelake PS, Blann AD (2009) Circulating endothelial cells and circulating progenitor cells in breast cancer: relationship to endothelial damage/dysfunction/apoptosis, clinicopathologic factors, and the Nottingham Prognostic Index. Neoplasia 11: 771-779.

Gupta M (2007) Circulating endothelial cells and circulating endothelial cell progenitors as surrogate markers for determining response to antiangiogenic agents. Clin Colorectal Cancer 6: 337-338.

Hebbar M, Peyrat JP (2000) Significance of soluble endothelial molecule E-selectin in patients with breast cancer. Int J Biol Markers 15: 15-21.

Hurwitz H, Fehrenbacher L, Novotny W, Cartwright T, Hainsworth J, Heim W, Berlin J, Baron A, Griffing S, Holmgren E, Ferrara N, Fyfe G, Rogers B, Ross R, Kabbinavar F (2004) Bevacizumab plus irinotecan, fluorouracil, and leucovorin for metastatic colorectal cancer. $N$ Engl J Med 350: $2335-2342$.
Kemeny N, Braun Jr. DW (1983) Prognostic factors in advanced colorectal carcinoma. Importance of lactic dehydrogenase level, performance status, and white blood cell count. Am J Med 74: 786-794.

Koch AE, Halloran MM, Haskell CJ, Shah MR, Polverini PJ (1995) Angiogenesis mediated by soluble forms of E-selectin and vascular cell adhesion molecule-1. Nature 376: 517-519.

Koutras AK, Starakis I, Kyriakopoulou U, Katsaounis P, Nikolakopoulos A, Kalofonos HP (2011) Targeted therapy in colorectal cancer: current status and future challenges. Curr Med Chem 18: 1599-1612.

Kumar H, Heer K, Lee PW, Duthie GS, MacDonald AW, Greenman J, Kerin MJ, Monson JR (1998) Preoperative serum vascular endothelial growth factor can predict stage in colorectal cancer. Clin Cancer Res 4: 1279-1285.

Kumar P, Amin MA, Harlow LA, Polverini PJ, Koch AE (2003) Src and phosphatidylinositol 3-kinase mediate soluble E-selectin-induced angiogenesis. Blood 101: 3960-3968.

Landt S, Wehling M, Heidecke H, Jeschke S, Korlach S, Stöblen F, Schmid P, Blohmer JU, Lichtenegger W, Sehouli J, Kümmel S (2011) Prognostic significance of angiogenic factors in uterine cervical cancer. Anticancer Res 31: 2589-2595.

Li B, Sharpe EE, Maupin AB, Teleron AA, Pyle AL, Carmeliet P, Young PP (2006) VEGF and PlGF promote adult vasculogenesis by enhancing EPC recruitment and vessel formation at the site of tumor neovascularization. FASEB J 20: 1495-1497.

Mancuso P, Bertolini F (2010) Circulating endothelial cells as biomarkers in clinical oncology. Microvasc Res 79: 224-228.

Matsusaka S, Mishima Y, Suenaga M, Terui Y, Kuniyoshi R, Mizunuma N, Hatake K (2011) Circulating endothelial progenitors and CXCR4-positive circulating endothelial cells are predictive markers for bevacizumab. Cancer 117: 4026-4032.

Oh IY, Yoon CH, Hur J, Kim JH, Kim TY, Lee CS, Park KW, Chae IH, Oh BH, Park YB, Kim HS (2007) Involvement of E-selectin in recruitment of endothelial progenitor cells and angiogenesis in ischemic muscle. Blood 110: 3891-3899.

Ramcharan SK, Lip GYH, Stonelake PS, Blann AD (2013) Angiogenin outperforms VEGF, EPCs and CECs in predicting Duke's stage in colorectal cancer. Eur J Clin Invest 43: 801-808.

Ronzoni M, Manzoni M, Mariucci S, Loupakis F, Brugnatelli S, Bencardino K, Rovati B, Tinelli C, Falcone A, Villa E, Danova M (2010) Circulating endothelial cells and endothelial progenitors as predictive markers of clinical response to bevacizumab-based first-line treatment in advanced colorectal cancer patients. Ann Oncol 21: 2382-2389.

Rowand JL, Martin G, Doyle GV, Miller MC, Pierce MS, Connelly MC, Rao C, Terstappen L (2007) Endothelial cells in peripheral blood of healthy subjects and patients with metastatic carcinomas. Cytometry A 71: 105-113.

Rykala J, Przybylowska K, Majsterek I, Pasz-Walczak G, Sygut A, Dziki A, Kruk-Jeromin J (2011) Angiogenesis markers quantification in breast cancer and their correlation with clinicopathological prognostic variables. Pathol Oncol Res 17: 809-817.

Sato H, Usuda N, Kuroda M, Hashimoto S, Maruta M, Maeda K (2010) Significance of serum concentrations of E-selectin and CA19-9 in the prognosis of colorectal cancer. Jpn J Clin Oncol 40: 1073-1080.

Segerstrom L, Fuchs D, Backman U, Holmquist K, Christofferson R, Azarbajani F (2006) The anti-VEGF antibody bevacizumab potently reduces the growth rate of high-risk neuroblastoma xenografts. Pediatr Res 60: $576-581$.

Shimoyama S, Yamasaki K, Kawahara M, Kaminishi M (1999) Increased serum angiogenin concentration in colorectal cancer is correlated with cancer progression. Clin Cancer Res 5: 1125-1130.

Takahashi Y, Kitadai Y, Bucana CD, Cleary KR, Ellis LM (1995) Expression of vascular endothelial growth factor and its receptor, KDR, correlates with vascularity, metastasis, and proliferation of human colon cancer. Cancer Res 55: 3964-3968.

Twelves C, Wong A, Nowacki MP, Abt M, Burris 3rd H, Carrato A, Cassidy J, Cervantes A, Fagerberg J, Georgoulias V, Husseini F, Jodrell D, Koralewski P, Kröning H, Maroun J, Marschner N, McKendrick J, Pawlicki M, Rosso R, Schüller J, Seitz JF, Stabuc B, Tujakowski J, Van Hazel G, Zaluski J, Scheithauer W (2005) Capecitabine as adjuvant treatment for stage III colon cancer. N Engl J Med 352: 2696-2704.

UK Government statistics (2014) http://www.statistics.gov.uk/hub/healthsocial-care/health-of-the-population/causes-of-death/index.html. 
Willett CG, Boucher Y, Duda DG, di Tomaso E, Munn LL, Tong RT, Kozin SV, Petit L, Jain RK, Chung DC, Sahani DV, Kalva SP, Cohen KS, Scadden DT, Fischman AJ, Clark JW, Ryan DP, Zhu AX, Blaszkowsky LS, Shellito PC, Mino-Kenudson M, Lauwers GY (2005) Surrogate markers for antiangiogenic therapy and dose-limiting toxicities for bevacizumab with radiation and chemotherapy: continued experience of a phase I trial in rectal cancer patients. J Clin Oncol 23: 8136-8139.

Werther K, Christensen IJ, Brünner N, Nielsen HJ (2000) Soluble vascular endothelial growth factor levels in patients with primary colorectal carcinoma. The Danish RANX05 Colorectal Cancer Study Group. Eur J Surg Oncol 26: 657-662.
Yang JC, Haworth L, Sherry RM, Hwu P, Schwartzentruber DJ, Topalian SL, Steinberg SM, Chen HX, Rosenberg SA (2003) A randomized trial of bevacizumab, an anti-vascular endothelial growth factor antibody, for metastatic renal cancer. New Engl J Med 349: 427-434.

This work is published under the standard license to publish agreement. After 12 months the work will become freely available and the license terms will switch to a Creative Commons AttributionNonCommercial-Share Alike 3.0 Unported License. 